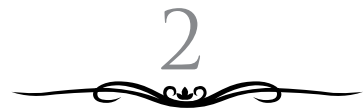

\title{
PENGEMBANGAN WIKI KAMPUS SEBAGAI MEDIA PENGETAHUAN KOMUNITAS DI PERPUSTAKAAN PERGURUAN TINGGI
}

\author{
Abdurrakhman Prasetyadi, Danang Dwijo Kangko, D.W. Ari Nugroho \\ Universitas Bina Nusantara Jakarta \\ romanintan@gmail.com
}

\begin{abstract}
This study aims tocreate category of knowledge communities in university library, designing the prototype of an online encyclopedia of knowledge communities in the university library, and testing a prototype of an online encyclopedia of knowledge communities. The method used is the analysis of web content of the comunities website at IPB and developmentprotoype using the MediaWiki software. The first results of this study are categories of knowledge created consisting of the main knowledge about the student association, student activity units, other communities, the terms of the campus and the surrounding of the campus. Second, in designing a prototype of Wiki Kampus make a data flow diagrams, system infrastructure, and installation. Furthermore, installation of MediaWikiincluding by several stages: downloading and extracting the file master MediaWiki on a web server, set-up the master files MediaWiki, determine the format page categorizing and customize the user interface, and set up a user account for students. Third, Wiki Kampus tested by some students of Master of Information Technology for Libraries (MTP) at IPB and the results is function well.
\end{abstract}

Keywords: knowledge communities, MediaWiki, online encyclopedia, students, and Wiki Kampus, 


\begin{abstract}
Abstrak
Kajian ini bertujuan untuk membuat kategori pengetahuan komunitas di perpusatakaan perguruan tinggi, merancang prototipe ensiklopedia daring pengetahuan komunitas di perpustakaan perguruan tinggi, dan melakukan ujicoba prototipe ensiklopedia daring pengetahuan komunitas. Metode yang digunakan yaitu analisis konten web komunitas di IPB dan pengembangan prototipe Wiki Kampus menggunakan perangkat lunak MediaWiki.Hasil dari kajian ini yaitu kategori pengetahuan yang dibuat terdiri dari pengetahuan utama komunitas seperti himpunan mahasiswa, unit kegiatan mahasiswa, komunitas lain, istilah-istilah kampus dan lingkungan sekitar kampus. Sedangkan, hasil perancanganprototipe Wiki Kampus terdiri dari pembuatandata flow diagram, perencanaan infrastruktur sistem dan penginstalasian perangkat lunak MediaWiki.Penginstalasian MediaWiki melalui beberapa tahapan diantaranya mengunduh dan mengekstraksi file master MediaWiki pada server web, melakukan set-up file master MediaWiki, menentukan format page categorizing dan mengkustomisasi tampilan pengguna, serta menyiapkan user account untuk mahasiswa. Hasil ujicoba Wiki Kampus dilakukan dengan beberapa mahasiswa program Magister Teknologi Informasi Perpustakaan (MTP) IPB berjalan lancar dan aplikasi berfungsi dengan baik.
\end{abstract}

Kata kunci: Ensiklopedia daring, Perpustakaan perguruan tinggi,MediaWiki, dan Wiki Kampus,

\title{
A. Pendahuluan
}

Perguruan tinggi(PT) di Indonesia saat ini sedang giat-giatnya untuk meningkatkan peringkat Webometricsnya, baik dari peringkat situs webcorporateataupun repositorinya. Sebagai institusi pendukungperguruan tinggi, Perpustakaan pada perguruan tinggitelah banyak membantu meningkatkan peringkat Webometrics dengan menghimpun dan menyebarkan 
knowledge repository asset ${ }^{1}$. Salah satunya yaitu dengan dengan mengembangkan repositori dan online journalyang kaya akan konten digital. Karena, salah satu kriteria penilaian Webometrics yaituOpenness terkait jumlah file dokumen (.pdf, .ps, .doc, .ppt) yang online/open di bawah domain situs web perguruan tinggi yang tertangkap mesin pencari/Google Scholar.

Fenomenaopen dokumen di atas banyak menyedot minat mahasiswa menggunakan media seperti repositori dan online journal di Perpustakaan perguruan tinggi. Akan tetapi tidak sedikit juga, mahasiswa yang memanfaatkan fasilitas hot spot untuk mengeksplor situs ensiklopedia daring agar menambah wawasannya. Seperti yang diungkapkan oleh Margawi,pencarian informasi tidak selalu melalui situs-situs mesin pencari seperti Google, Yahoo, MSN dan lain-lain.Banyak pengguna kini mulai meliriksitus-situs ensiklopedia daring semacam Wikipedia untuk mencari berbagai macam informasi yang disediakan ${ }^{2}$.

Di sisi lain, pada perguruan tinggi terdapat banyak komunitas-komunitas mahasiswa yang memiliki visi dan misi yang berbeda-beda. Seperti komunitas Rohani Islam (Rohis)di Institut Pertanian Bogor (IPB) yang memiliki kegiatan khusus bagi mahasiswa, anggota pengurus masjid dan Korps PMI, untuk menggalang kegiatan kemanusiaan seperti donor darah.Komunitas mahasiwa tersebut memilikibanyak kegiatan dan informasi yang banyak namun belum terdokumentasikan dengan baik.

Melihat fenomena di atas, seharusnya Perpustakaan perguruan tinggidapat mengembangkan sebuah media ensiklopedia daring untuk mengumpulkan, mengelola dan mendiseminasikanseluruh pengetahuan dari tiap komunitas

1 Puspitasari, D \& Anawati, N.D“Peran Perpustakaan dalam Mendukung Universitas Airlangga Menuju World Class University melalui Peningkatan Webormetrics".Diakses dari http://www.journal.unair.ac.id pada tanggal 15 mei 2017.

2 Margawi, R,Pengembangan Aplikasi Wiki Wisatapedia Jogja MenggunakanRich Internet Application, (Yogyakarta: Universitas Atma Jaya, 2009). 
mahasiswa.Maka dari itu perumusan masalah dari kajian ini yaitu,melakukan pengembangan ensiklopedia daring Wiki Kampus sebagai media pengetahuan komunitas di Perpustakaan perguruan tinggi.Pengembangan Wiki Kampus akan berkolaborasi dengan beberapa elemen seperti anggota komunitas dan staf Perpustakaanperguruan tinggi. Selain itu, mengakuisisi informasi yang dimiliki oleh beberapa komunitas mahasiswa di salah satu perguruan tinggi Negeri.

Menurut Sanjaya, ensiklopedia daring merupakan situs webyang mengusung konsep web 2.0. Web 2.0 seperti yang ditekankan oleh beberapa pihak,merupakansocial network atau jalinan sosial antara penggunanya.Karakteristikensiklopedia daring yang cocok dengan karakter web 2.0 yaitu adanya partisipasi dari pengguna dalam berkolaborasi mengembangkan pengetahuan. Hal ini mengingatkan akan pemberian kepercayaan kepada pengguna internet untuk dapat berpartisipasi dalam berbagi pengetahuan di situs Wikipedia ${ }^{3}$.

Adapun tujuan dari kajian ini adalah 1) membuatkategori pengetahuan komunitas di Perpustakaan perguruan tinggi, 2) merancang prototipeensiklopedia daring pengetahuan komunitas di Perpustakaan perguruan tinggi, dan 3) melakukan ujicoba prototipeensiklopedia daring pengetahuan komunitas. Sedangkan manfaat yang diperoleh dari kajian ini ialah: 1) meningkatkan peran Perpustakaan perguruan tinggi dalam mendorong peringkat Webometrics lembaga, 2) berpotensi untuk menjadi rujukan atau pusat repositori pengetahuan komunitas perguruan tinggi, dan 3) menjadi sumber referensi digital bagi mahasiswa di Perpustakaanperguruan tinggi. Ruang lingkup dari kajian ini ialahensiklopedia daringyang dikembangkan dan diberi namaWiki Kampus,yangdispesialisasikan untuk mengakuisisi, mengelola, serta mendiseminasikan pengetahuantentang komunitas mahasiswa di IPB.

${ }^{3}$ Sanjaya, Ridwan. Web 2.0 “Gelombang Baru Di Dunia”.Di akses dari pada tanggal 14 januari 2017. 
Metode yang digunakan yaitu analisis konten webbeberapa komunitas mahasiswa di IPB dan pengembangan prototipe ensiklopedia daring.Berikut ini merupakan alir dari pengembangan Wiki Kampus yang dilakukan, lihat Gambar 1.

Gambar 1.Alur pengembangan Wiki Kampus

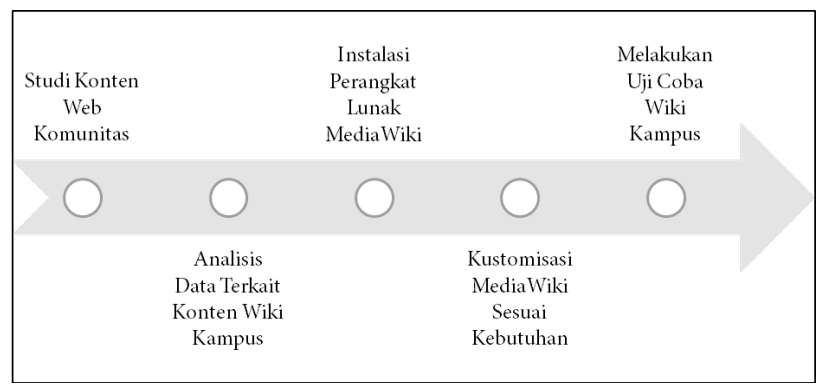

Jenis materialkonten untukWiki Kampusyang dikumpulkan dari beberapasitus web komunitas di IPBdi golongkan berdasarkan karakter obyek, sumber dan output-nya seperti pada Tabel 1.

Tabel 1. Material konten untuk Wiki Kampus

\begin{tabular}{lll}
\hline \multicolumn{1}{c}{ Karakteristik Obyek } & \multicolumn{1}{c}{ Sumber } & Hasil/Output \\
\hline Teks & Doc,Pdf & Html \\
\hline Foto & Raw+JPEG, M-Raw+JPEG & JPEG, TIFF \\
\hline Video & MPEG-4 & Mov, MP4 \\
\hline
\end{tabular}

Sebelum mengembangkan Wiki Kampus, dilakukan analisis SWOT terlebih dahulu.Analisis SWOT merupakan bentuk analisis situasi dan juga kondisi yang bersifat deskriptif (memberi suatu gambaran).Analisis ini menempatkan situasi dan juga kondisi sebagai faktor masukan, kemudian dikelompokkan menurut kontribusinya masing-masing. Satu hal yang perlu diingat baikbaik oleh para pengguna analisis ini, bahwa analisis SWOT ini semata-mata sebagai sebuah analisa yang ditujukan untuk menggambarkan situasi yang sedang dihadapi, dan bukan sebuah alat analisa ajaib yang mampu memberikan jalan keluar yang bagi permasalahan yang sedang dihadapi ${ }^{4}$. Berikut analisis SWOT yang

${ }^{4}$ Nugroho, D. A., \& Prasetyadi, A. (2016). Multimedia Science Library 
bisa digambarkandalam pengembangan Wiki Kampus seperti pada Gambar 2.

Gambar 2. Analisis SWOT Wiki Kampus

\section{STRONG}

1. Mengusung konsep web 2.0 dimana pengguna dapat ikut mengisi dan mengkoreksi konten/materi di Wiki Kampus

2. Ikut berperan dalam meningkatkan peringkat Webometrics lembaga perguruan tingginya

\section{WEAKNESS}

1. Kurangnya infrastruktur di perpustakaan perguruan tinggiuntuk mengelola informasi yang terus update dari tiap komunitas

2. SDM yang menguasai sekaligus bidang IT, perpustakaan, dan humas masih sedikit

\section{OPPORTUNITY}

1. Informasi tentang ilmu pengetahuan sudah banyak disajikan di internet namun khususnya pengetahuan tentang komunitas mahasiswa di Indonesia masih sedikit terdokumentasikan dan disebarluaskan

2. Pengetahuan tentang komunitas mahasiswa dengan format digital masih jarang atau terbatas yang bisa diakses di internet

\section{B. Pembahasan}

\section{Kategori Pengetahuan Komunitas}

PadaTabel2,telah dijabarkanmengenaikategoripengetahuan komunitas yang telah dianalisis dan dibuat. Dimana kategori utama diklasifikasikan berdasarkan kebutuhan pengetahuan di perpustakaan perguruan tinggi, untuk mahasiswa diantaranya: 1)

(Makalah). Bogor: IPB. 
Himpunan mahasiswa; 2) Unit kegiatan mahasiswa; 3) Komunitas lain; 4) Istilah kampus; dan 5) Lingkungan komunitas.

Tabel 2. Kategori Pengetahuan Komunitas Wiki Kampus

\begin{tabular}{|c|c|c|}
\hline Kategori & Pranala & Sub Pranala \\
\hline \multirow{13}{*}{$\begin{array}{l}\text { 1. Himpunan } \\
\text { Mahasiswa }\end{array}$} & Fak. Pertanian & Himagron \\
\hline & & \\
\hline & & HMIT \\
\hline & & Miseta \\
\hline & Fak. Kedokteran & Ruminansia \\
\hline & Hewan & \\
\hline & & Ornithologi \\
\hline & Fak. Perikanan dan & Himaqua \\
\hline & Kelautan & \\
\hline & & Himasper \\
\hline & & Himasilkan \\
\hline & Fak. Peternakan & Himaproter \\
\hline & & Himasiter \\
\hline \multirow{10}{*}{$\begin{array}{l}\text { 2. Unit Kegiatan } \\
\text { Mahasiswa } \\
\end{array}$} & Bidang Seni dan & Agria Sawara \\
\hline & Budaya & \\
\hline & & Gentra Kaheman \\
\hline & Bidang Olah Raga & Bola Basket \\
\hline & & PS Merpati Putih \\
\hline & & Sepak Bola \\
\hline & Bidang Kegiatan & Menwa \\
\hline & Khusus & \\
\hline & & Mapala (Pencinta Alam) \\
\hline & & Korps PMI \\
\hline \multirow[t]{7}{*}{ 3. Komunitas Lain } & Komunitas & Komunitas \\
\hline & Mahasiswa Daerah & Barat \\
\hline & & Komunitas Sulawesi \\
\hline & & Selatan \\
\hline & & Komunitas NTT \\
\hline & Komunitas Hobi & Komunitas Bike to \\
\hline & & Campus \\
\hline \multirow[t]{4}{*}{ 4. Istilah Kampus } & Formal & KRS \\
\hline & & SKS \\
\hline & & IPK \\
\hline & & Dosen Wali \\
\hline
\end{tabular}




\begin{tabular}{lll}
\hline & & Disertasi \\
\hline & & Tesis \\
\hline & KKN \\
\hline & Kon Formal & Rohis \\
\hline & & Pemira \\
\hline & & Presma \\
\hline $\begin{array}{c}\text { 5. Lingkungan } \\
\text { Komunitas }\end{array}$ & Rumah Kost & - \\
\hline & Warung Makan & - \\
\hline & Rental Komputer & - \\
\hline & Fotokopi & - \\
\hline
\end{tabular}

\section{Perancangan Wiki Kampus}

Perancangan Wiki Kampus melibatkan beberapa elemen dengan tugas dan fungsinya masing-masing, seperti: mahasiswa, staf perpustakaan,dan kepala perpustakaan perguruan tinggi. Seperti pada gambar 3 dijelaskan bahwa staf perpustakaan memiliki hak untuk membuat halaman baru, memperbaiki konten, dan melihat histori halaman.Sedangkan mahasiswa dapat mengisi halaman yang telah dibuka oleh staf perpustakaan, melakukan pengisian dan mengedit pada halaman tersebut, dapat membuat halaman lainnya dan keseluruhan pengetahuan komunitas mahasiswa terekam dengan baik.Terakhir, kepala perpustakaan berfungsi menyediakan prosedur penggunaan, membuat akun pengguna dan mengelola pengguna Wiki Kampus ini.Berikut merupakandata flow diagram rancangan fungsi utama pada Wiki Kampus. 
Gambar 3.Data Flow Diagram

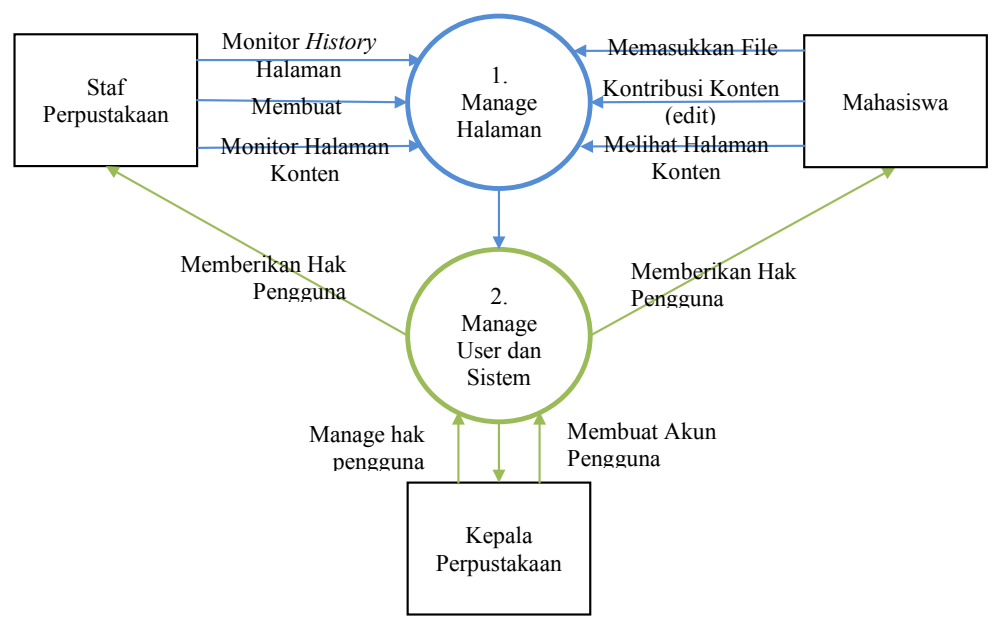

Sumber: Dimodifikasi dari Cassandra ${ }^{5}$

Infrastruktur sistem Wiki Kampus yang direncanakan terdiri dari 2 komputer (staf perpustakaan, dan manajer perpustakaan), yang dihubungkan ke komputer server web Wiki Kampus dan server DHCP.Dalam hal ini, jaringan yang digunakan Wifi dan local area network (LAN) yang dapat terhubung ke berbagai perangkat seperti laptop, smartphone, dan tablet mahasiswa. Sedangkan kapasitas server $3 \mathrm{~TB}$, backup data dilakukan dengan menggunakan NAS (Network Attached Storage).Network Attached Storage (NAS) adalah sebuah server dengan sistem operasi yang dikhususkan untuk melayani kebutuhan berkas data.NAS dapat di akses langsung melalui jaringan area lokal dengan protokol seperti TCP/IP. Berikut gambar topologi dari infrastruktur sistem Wiki Kampus:

${ }^{5}$ Cassandra, C., Tambotoh, J., \& Papilaya, F. S. “Pemanfaatan MediaWiki Sebagai Knowledge Management Toolsuntuk Mendukung Implementasi E-Learning" dalamJurnal Manajemen Teknologi Vol.14, No.3, 2015., 334-347. 
Gambar 4. Infrastruktur sistem Wiki Kampus di perpustakaan PT

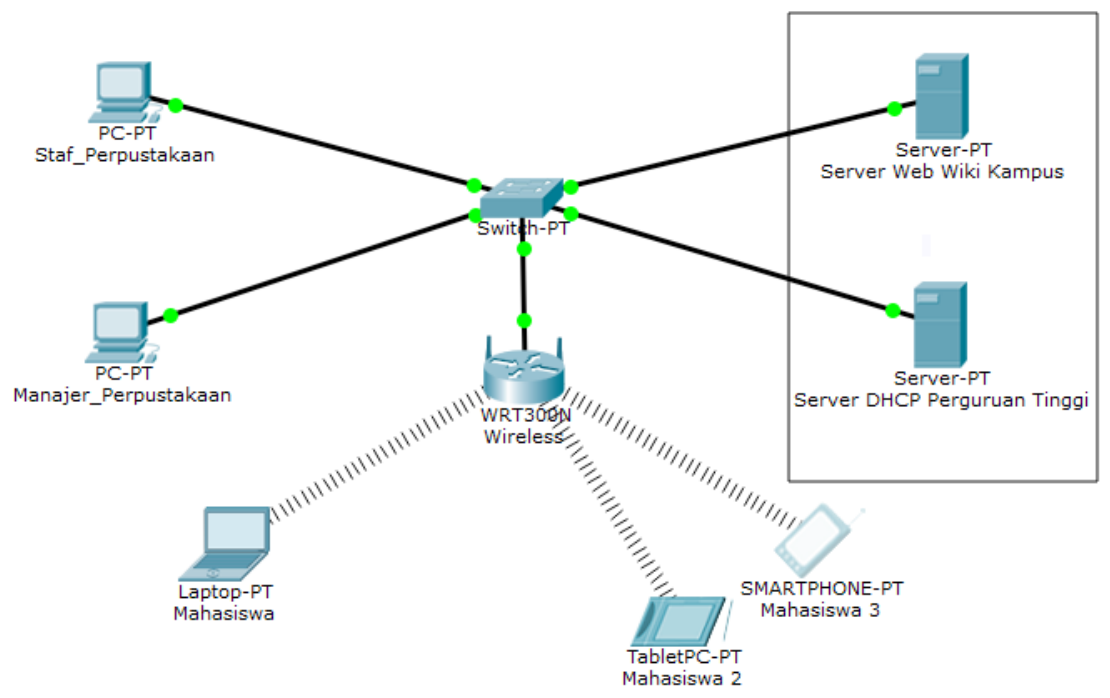

Seperti yang dijelaskan sebelumnya kajian ini merupakan pengembangan ensiklopedia daring menggunakan perangkat lunak gratis yaituMediaWiki.Untuk itu, maka pendekatan pengembangan sistem yang dipilih adalah dengan menggunakan metode pengembangan sistem prototyping ${ }^{4}$. Proses pembuatan prototype Wiki Kampus antara lain: (a) Mengunduh dan mengekstraksi file master MediaWiki pada server web, (b) Melakukan set-up file master MediaWiki, (c) Menentukan format page categorizing dan mengkustomisasi tampilan pengguna, serta(d) Menyiapkan user account untuk mahasiswa ${ }^{6}$. Berikut merupakan penjelasan dari pembuatan prototipeWiki Kampus:

a). Mengunduh dan mengekstraksi MediaWiki

Pengunduhan file master MediaWiki dilakukan melalui laman MediaWiki. Setelah melakukan pengunduhan tersebut selanjutnya dilakukan ekstraksi dan menyimpan file MediaWiki ke dalam server web.

${ }^{6}$ MediaWiki.(2016). MediaWiki Instalation. Diakses dari MediaWiki. org pada tanggal 14 Desember 2016 
Gambar 5. Mengekstraksi file master MediaWiki

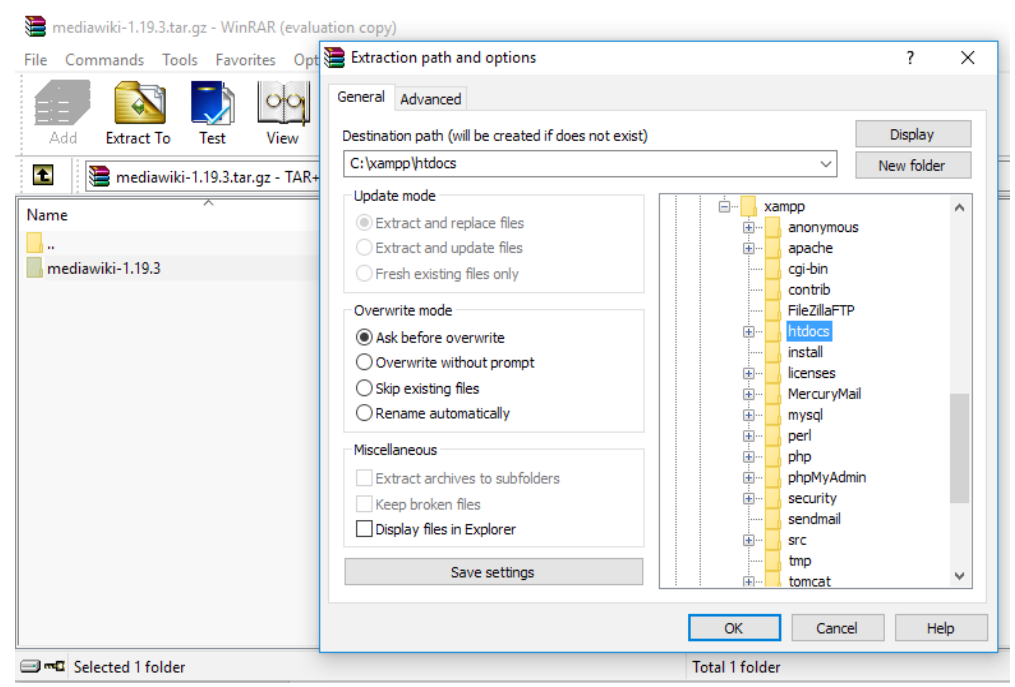

b). Melakukan set-up MediaWiki

Set-up MediaWiki untuk sementara dilakukan via localhost (http://localhost/foldermediawiki), dan melakukan set-up wiki.

Gambar 6. Akses via browser

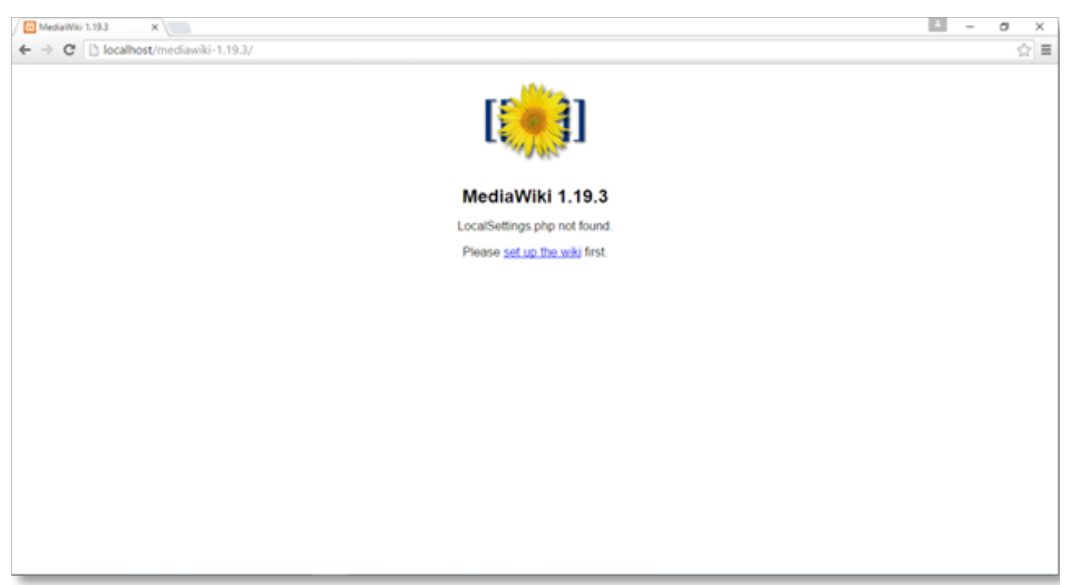


Pada proses ini dilakukan pemilihanbahasa yang akan digunakan dan bahasa Wiki Kampus. Penulis menggunakan Bahasa Indonesia untuk Wiki Kampus dan melakukan konfigurasi database yang akan digunakan Wiki Kampus diantaranya memasukkan nama host (dalam hal ini localhost), nama basis data (my_wiki), mengisi prefiks tabel database (my_wiki1) dan memasukkan username dan password basis data yang defaultnya adalah root dan password kosong.

Gambar 7. Konfigurasi basis data Wiki Kampus

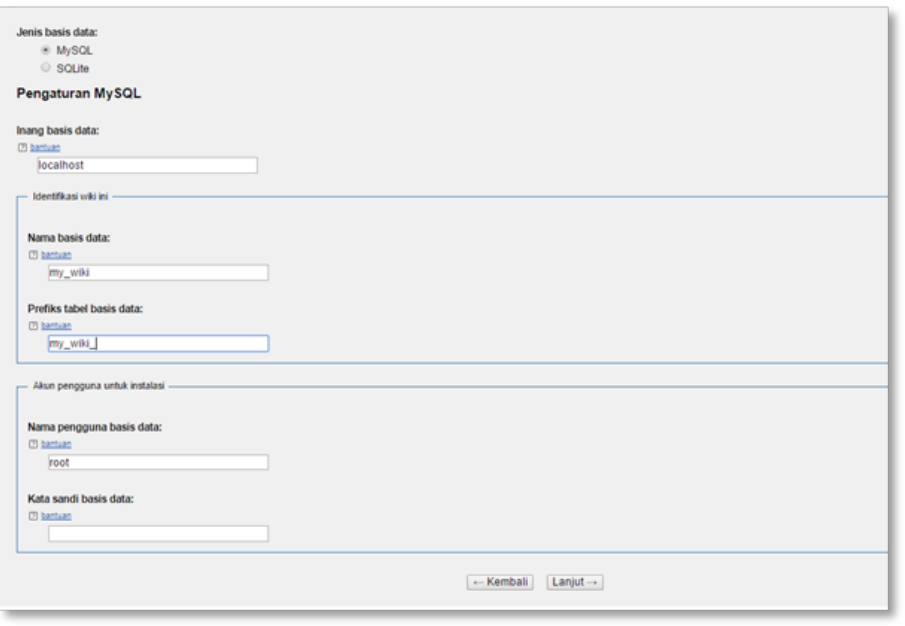

c). Menentukan format page categorizing dan kustomisasi tampilan

Dalam menentukan format page categorizing, penulis memilih tipe list atau daftar kategori pengetahuan komunitas beserta pranala link internal maupun eksternalnya.Sedangkan untuk tampilan dilakukan beberapa kustomisasi seperti penambahan logo kampus, menyertai ucapan selamat datang dan mengisi informasi menu tentang Wiki Kampus. Berikut tampilan dari page categorizing dan tampilan halaman utama Wiki Kampus: 
Gambar 8.Kategori pengetahuan komunitas dalam bentuk list dan tampilan halaman utama bagi pengguna

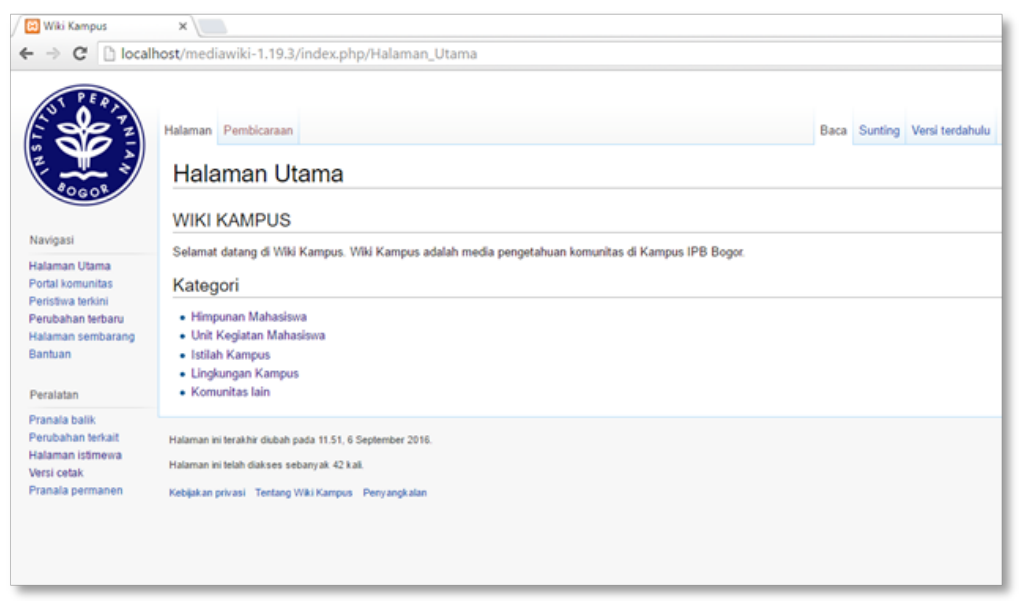

d). Menyiapkan user account mahasiswa

Pembuatan user account bagi mahasiswa dilakukan pada saat login ke laman administrator.

Gambar 9. Membuat akun pengguna

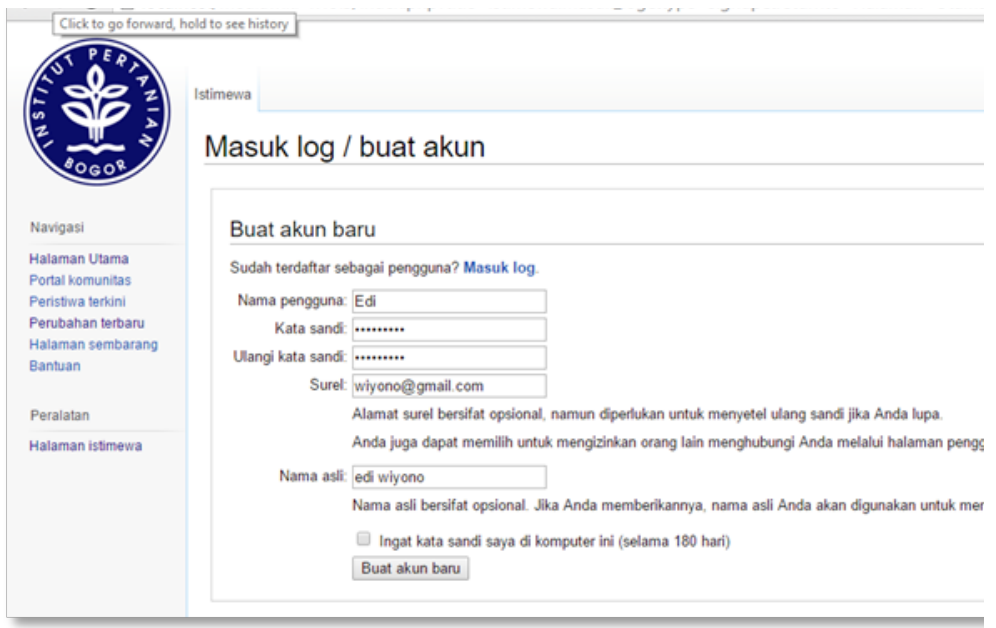




\section{Hasil Uji Coba Wiki Kampus}

Langkah terakhir dari pengembangan Wiki Kampus yaitu, melakukan uji coba.Uji coba Wiki Kampus dilakukan dengan menyunting dan menelusursecara riil oleh mahasiswa untuk mengetahui kegunaan dari media MediaWiki. Proses ujicoba aplikasi dilakukan oleh beberapa rekan mahasiswa di program Magister Teknologi Informasi untuk Perpustakaan (MTIP)-IPB, dimana ada beberapa tugas yang terkait dengan pengembangan sistem perpustakaan. Berikut beberapa ujicoba yang dilakukan oleh mahasiswa MTIP:

Gambar 10. Penyuntingan konten tentang UKM Mapala oleh mahasiswa

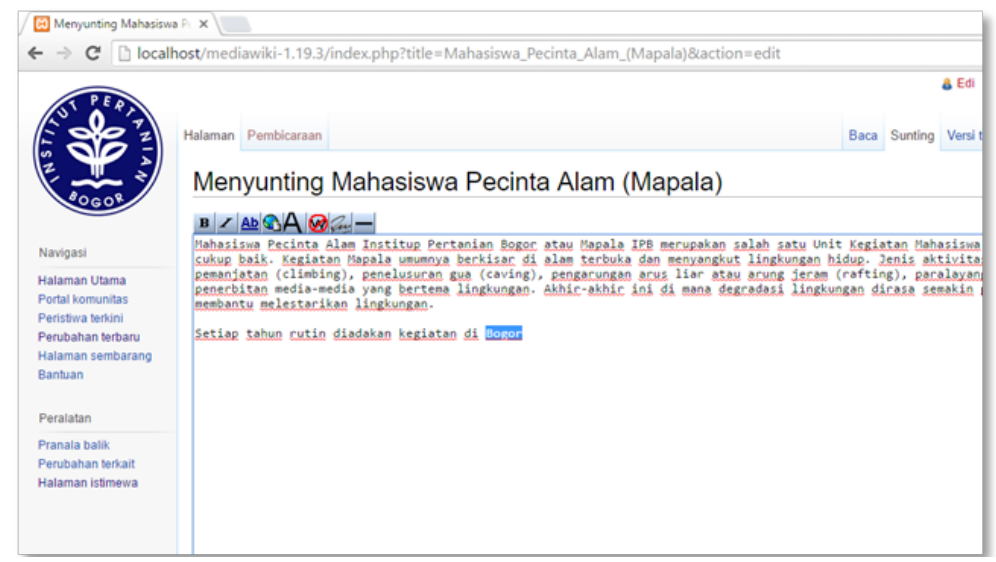

Pada gambar di atas telah dilakukan penyuntingan artikel UKM Mapala oleh mahasiswa MTIP.Penyuntingan berjalan dengan baik dan tidak ada kendala apapun, mahasiswa pun dapat menambahkan pranala internal maupun eksternal untuk memberikan konten-konten lain yang terkait dengan artikel Mapala IPB. 
Gambar 11. Mengamati peran mahasiswa MTIP IPB yang melakukan perubahan terbaru pada Wiki Kampus

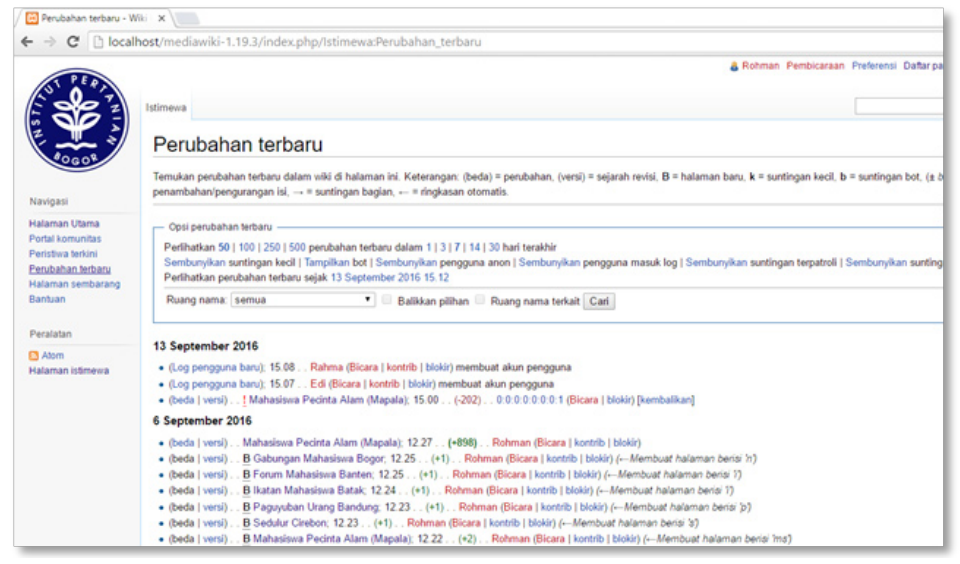

Pada gambar di atas ditampilkan history perubahan terbaru yang dilakukan oleh setiap mahasiswa baik itu penyuntingan ataupun penghapusan tiap konten Wiki Kampus.Ujicoba selanjutnya yaitu melakukan penelusuran terhadap konten-konten yang telah diisi oleh mahasiswa MTIP IPB, berikut hasil ujicoba penelusuran seperti pada Gambar 12.

Gambar 12. Hasil penelusuran tentang UKM dan kemudian Mapala oleh mahasiswaMTIP IPB

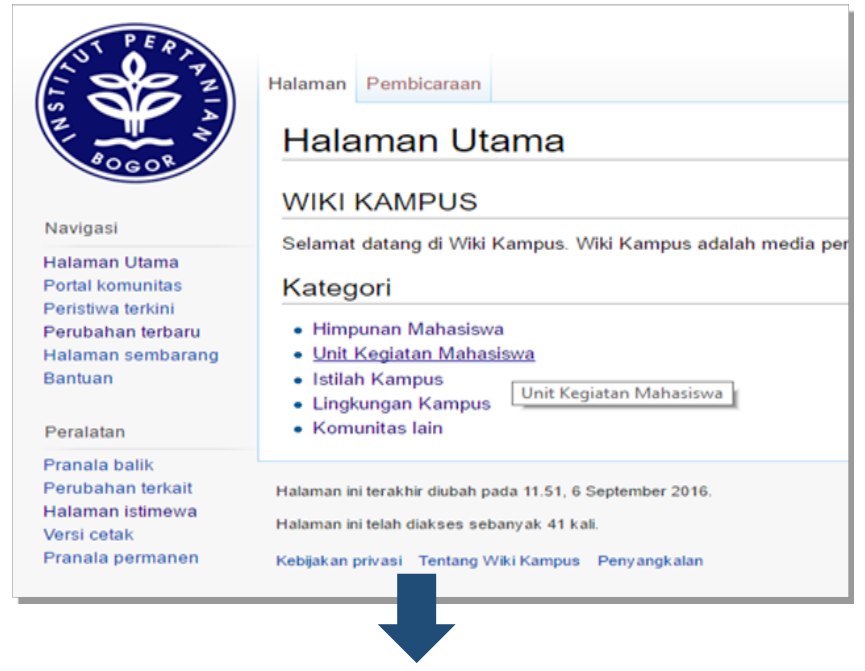



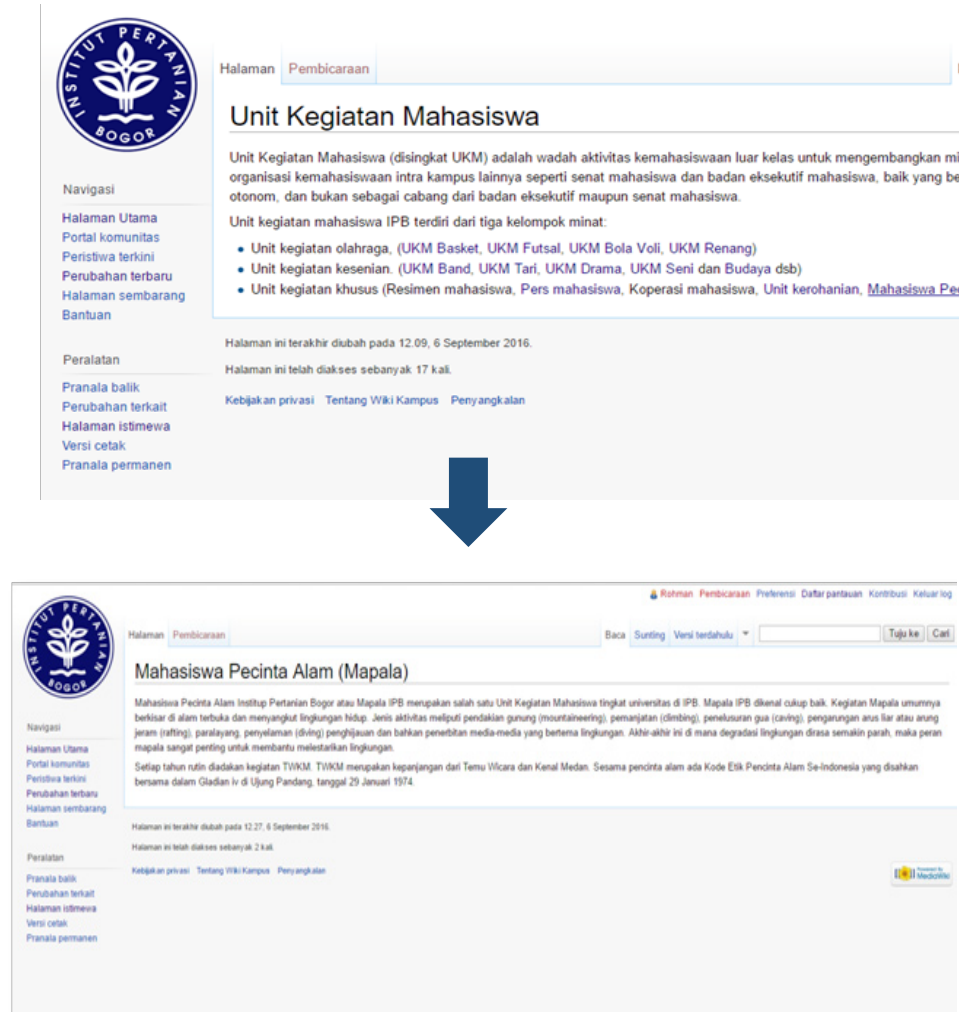

\section{Simpulan}

Kajian ini dilakukan atas permasalahan yang ada yaitu,belum terdokumentasikannya informasi mengenai pengetahuan komunitas di perguruan tinggi, kurangnya peran perpustakaan dalam ikut meningkatkan peringkat Webometrics lembaganya, dan pentingnya mengembangkan ensiklopedia daring untuk berbagi dan berkolaborasi pengetahuan diantara mahasiswa. Oleh karena itu, dikembangkan suatu ensiklopedia daring untuk pengetahuan komunitas di perpustakaan perguruan tinggi dengan mengusung konsep web 2.0.Dimana ensiklopedia daring sesuai dengan konsep 2.0 yaitu berkolaborasi dan berbagi pengetahuan. Adapun ensiklopedia daring ini diberi nama Wiki Kampus.Wiki Kampus dikembangkan dengan menggunakan perangkat lunak gratis MediaWiki agar dapat dilakukan beberapa kustomisasi sesuai kebutuhan. 
Pengembangan sistem dilakukan dengan membuat kategori pengetahuan komunitas terlebih dahulu, merancang prototipe, dan melakukan ujicoba aplikasi Wiki Kampus.Kategori pengetahuan terdiri dari informasi mengenai himpunan mahasiswa, ukm, komunitas lain, istilah kampus dan lingkungan sekitar kampus. Kemudian dalam merancang prototipe Wiki Kampus terdiri dari pembuatan data flow diagram, perencanaan infrastruktur sistem dan penginstalasian perangkat lunak MediaWiki.

Penginstalasian MediaWiki melalui beberapa tahapan diantaranya (a) Mengunduh dan mengekstraksi file master MediaWiki pada server web, (b) Melakukan set-up file master MediaWiki, (c) Menentukan format page categorizing dan mengkustomisasi tampilan pengguna, serta (d) Menyiapkan user account untuk mahasiswa. Ujicoba Wiki Kampus dilakukan oleh beberapa mahasiswa program Magister Teknologi Informasi untuk Perpustakaan (MTP) IPB.Mahasiswa diberikan tugas untuk menyunting konten dan menelusur hasil suntingan tersebut, hasilnya Wiki Kampus berjalan dengan baik dan lancar. 


\section{DAFTAR PUSTAKA}

Cassandra, C., Tambotoh, J., \& Papilaya, F. S."Pemanfaatan MediaWiki sebagai Knowledge Management Tools untuk Mendukung Implementasi E-Learning". Jurnal Manajemen Teknologi Vol.14, No.3, 2015.

Margawi, R.Pengembangan Aplikasi Wiki Wisatapedia Jogja Menggunakan Rich Internet Application, Yoogyakarta: Universitas Atma Jaya, 2009.

MediaWiki. MediaWiki. Retrieved from MediaWiki, dalam http:// www.mediawiki.orgdiakses 14 Desember 2016

Nugroho, D. A., \& Prasetyadi, A. Multimedia Science Library (Makalah). Bogor: IPB, 2016.

Puspitasari, D \& Anawati, N.D. "Peran Perpustakaan Dalam Mendukung Universitas Airlangga Menuju World Class University melalui Peningkatan Webormetrics".Diakses dari http://www.journal.unair.ac.iddiakses 15 mei 2017.

Sanjaya, Ridwan. Web 2.0 Gelombang Baru Di Dunia.Diakses dari .html/ diakses 14 januari 2017. 